УДК 159.923

DOI https://doi.org/10.32838/2709-3093/2021.2/10

\title{
Василенко I.A.
}

Південноукраїнський національний педагогічний університет

імені К.Д. Ушинського

\section{ОСОБЛИВОСТІ ЦІННІСНИХ ОРІЕНТАЦІЙ У МЕНЕДЖЕРІВ РІЗНОГО РІВНЯ УСПІШНОСТІ У ДІЯЛЬНОСТІ}

Сьогодні все більш очевидним стає той факт, що є потреба в менеджерах нової формації, здатних до конструктивної й ефективної діяльності в ринкових умовах, які відрізняються творчою активністю, вміють знаходити компетентні рімення в ситуачії невизначеності, підвищеного ризику, обмеженого часу і готові нести за них відповідальність. У зв'язку із цим теоретичне і практичне значення має вирішення проблеми дослідження успішності діяльності менеджерів. Психологічні особливості діяльності менеджера представлені значною кількістю як зарубіжних (Р. Блейк, М. Вудкок, Д. Френсіс, Дж. Грейсон, К. Кіллен, С. Ковалевскі), так і вітчизняних (В. Жигалов, Й. Завадський, В. Лозиия, М. Мартиненко, Г. Щокін) досліджень.

Мета дослідження - теоретичне обтрунтування та емпіричне дослідження ціннісних орієнтацій менеджерів різного рівня професійної успішності.

У дослідженні здійснено теоретико-методологічний аналіз проблеми самооцінки та типів батьківського ставлення до дітей молодшого шкільного віку; проаналізовано взаємозв'язки між показниками самооиінки дітей молодшого шкільного та типом батьківського ставлення; встановлено співвідношення між показниками, що вивчаються. Для вирішення зазначених теоретико-емпіричних завдань у дослідженні використано як теоретичні, так $і$ діагностичні (психометрично обтрунтовані й надійні) методи та методики.

Відповідно до мети роботи, на основі результатів психодіагностичних досліджень проаналізовано структуру, рівні вираженості і внесок професійних ціннісних орієнтацій менеджерів, що зумовлюють успішність їхньої професійної діяльності. На першому етапі емпіричного дослідження за допомогою методу корелячійного аналізу (за К. Пірсоном) проаналізовано значущі взаємозв'язки між показниками мотиваційно-ціннісної структури особистості та соціально-психологічною активністю менеджерів, установлено статистично значущі на 1\% та 5\% додатні та від 'ємні кореляційні зв'язки між показниками иіннісних орієнтацій та показниками мотиваторів соціально-психологічної активності менеджерів із низьким та високим рівнями успішності. За результатами якісного аналізу встановлено спеиифіку иіннісних орієнтацій у менеджерів різного рівня успішності в діяльності.

Ключові слова: иіннісні орієнтації, показники ціннісних орієнтацій, мотиватори соціально-психологічної активності менеджерів, низький та високий рівні успішності діяльності менеджерів.

Постановка проблеми. У сучасних соціальноекономічних умовах особливої актуальності набувають психологічні дослідження особливостей побудови професійної успішності менеджерів. Співробітники організації більше не розглядаються як пасивний персонал, кар'єрою якого займається керівництво конкретного підприємства. Навпаки, спостерігається тенденція зміщення цінностей у бік підвищення ролі людини в побудові власної кар'єри. Відзначаються зростання незалежності працівника, свобода вибору в плануванні кар'єри, пріоритет прихильності професії і власного життєвого шляху над прихильністю організації i, як наслідок, прийняття на себе відповідальності за прийняті рішення.
У вітчизняній психології аналіз розвитку особистості в ході професійної діяльності прийнято розглядати, спираючись на основні принципи системного підходу. Професійне становлення особистості тут розглядається як система, що складається 3 окремих компонентів, котрі утворюють деяку динамічну структурно-рівневу композицію, яка сама є підсистемою більшої системи - системи життєдіяльності (Абульханова-Славська).

Найбільш відомими роботами, в яких досліджувалися особистісні характеристики менеджера, є дослідження П. Керженцева, Р. Кричевського; професійно-значущі якості особистості менеджера та стиль його управління - О. Омарова, В. Рубахіна, О. Філіппова. 
Аналіз останніх досліджень і публікацій. Теоретико-методологічною основою проблеми є психологічні теорії розвитку особистості та концептуальних ідей щодо особливостей іiї становлення (Б.Г. Ананьєв, Б.Ф. Ломов); теоретичні положення про активність особистості, яка розкривається в ініціативному, самостійному та перетворюючому ставленні суб'єкта до дійсності, інших людей та до самого себе (С.Л. Рубінштейн, К.О. Абульханова-Славська); психологічні підходи до гуманізації професійної підготовки (Г.О. Балл, А. Маслоу, Д.О. Леонтьєв, В.В. Рибалка, В.М. Шепель); ідеї цілісності, єдності особистісного та професійного розвитку людини (Є.А. Клімов, Б.Г. Ананьєв, О.Г. Молл, К.К. Платонов, Н.В. Кузьміна, В.А. Семиченко, Е.Ю. Пряжнікова, В.Д. Шадріков, В.О. Якунін та ін.); положення про саморегуляцію як суб' єктивну умову реалізації особистістю діяльності (О.О. Конопкін, М.Й. Боришевський, Л.Д. Столяренко).

Виклад основного матеріалу дослідження. Дослідження припускає використання теоретичних методів, зокрема аналіз літератури, узагальнення та систематизація теоретичних даних; емпірічніх - спостереження, бесіда, тестування, анкетування. Обробка отриманих даних здійснювалася за допомогою статистичних методів: кількісного (за допомогою комп'ютерної програми SPSS 18.0 for Windows) та якісного (метод «профілів») аналізу.

У емпірічному дослідженні були використані психодіагностичні методики: «Діагностика мотиваторів соціально-психологічної активності особистості», «Морфологічний тест життєвих цінностей» (МТЖЦ), автори - В.Ф. Сопів,
Л.В. Карпушина, «Якір кар'єри», методика діагностики ціннісних орієнтацій в кар'єрі (Е. Шейна, переклад і адаптація В.А. Чікер, В.Е. Вінокурова), «Діагностика лідерських здібностей» (Е. Жариков, Е. Крушельницький). У дослідженні взяли участь 46 осіб: 27 чоловік та 19 жінок - менеджерів компанії у віці від 25 до 43 років.

У табл. 1 представлено результати кореляційного аналізу між показниками ціннісних орієнтацій та показниками мотиваторів соціальнопсихологічної активності менеджерів із низьким рівнем успішності, у табл. 2 - із високим рівнем успішності.

Встановлено від'ємні кореляційні зв'язки ( $\rho \leq$ $0,01)$ між досягненням успіху (Ду) та професійною компетентністю (Пк), менеджментом (Ме), автономією (Ав), стабільністю (Ст), допомогою людям (Сд), конкуренцією (Ко), інтеграцією стилів життя (Ісж) та додатний кореляційний зв'язок із підприємництвом (Пі). Виявлено від'ємний кореляційний зв'язок ( $<<0,01)$ між прагненням до влади (Пв) та професійною компетентністю (Пк), менеджментом (Ме), автономією (Ав), стабільністю (СТ), допомогою людям (Сд), конкуренцією (Ко) та додатний кореляційний зв'язок із підприємництвом (Пі). Установлено наявність від'ємних кореляційних зв'язків між тенденцією до групового визнання і поваги (Тп) та професійною компетентністю (Пк), стабільністю (Ст), допомогою людям (Сд), конкуренцією (Ко), інтеграцією стилів життя (Ісж).

Визначено додатні кореляційні зв'язки $(\rho \leq 0,01)$ між досягненням успіху (Ду) та професійною компетентністю (Пк), менеджментом (Ме), автоно-

Таблиця 1

Значимі коефіціснти кореляції між показниками ціннісних оріснтацій та показниками мотиваторів соціально-психологічної активності менеджерів із низьким рівнем успішності

\begin{tabular}{|c|c|c|c|}
\hline \multirow{2}{*}{$\begin{array}{c}\text { Показники мотиваторів } \\
\text { соціально-психологічної активності }\end{array}$} & \multicolumn{3}{|c|}{ Показники ціннісних оріснтацій } \\
\hline & $\begin{array}{c}\text { Досягнення } \\
\text { успіху }\end{array}$ & $\begin{array}{c}\text { Прагнення } \\
\text { до влади }\end{array}$ & $\begin{array}{c}\text { Тенденція } \\
\text { до групового визнання } \\
\text { і поваги }\end{array}$ \\
\hline Професійна компетентність & $-0,786^{* *}$ & $-0,914 * *$ & $-0,756^{* *}$ \\
\hline Менеджмент & $-0,357^{*}$ & $-0,248^{*}$ & \\
\hline Автономія (незалежність) & $-0,412^{*}$ & $-0,225^{*}$ & \\
\hline Стабільність & $-0,534^{*}$ & $-0,928 * *$ & $-0,946 * *$ \\
\hline Слугування добру & $-0,975 * *$ & $-0,956 * *$ & $-0,997 * *$ \\
\hline Конкуренція & $-0,945 * *$ & $-0,999 * *$ & $-0,965 * *$ \\
\hline Інтеграція стилів життя & $-0,225^{*}$ & & \\
\hline Підприємництво & $0,259^{*}$ & $0,292 *$ & \\
\hline
\end{tabular}

Примітка: 1) тут і далі нулі й коми опущені; 2) позначка ** $-\mathrm{p} \leq 0,01$; позначка * $-\mathrm{p} \leq 0,05$. 


\begin{tabular}{|c|c|c|c|}
\hline \multirow[b]{2}{*}{$\begin{array}{c}\text { Показники мотиваторів } \\
\text { соціально-психологічної активності }\end{array}$} & \multicolumn{3}{|c|}{ Показники ціннісних оріснтацій } \\
\hline & $\begin{array}{l}\text { Досягнення } \\
\text { успіху }\end{array}$ & $\begin{array}{l}\text { Прагнення } \\
\text { до влади }\end{array}$ & $\begin{array}{c}\text { Тенденція } \\
\text { до групового визнання } \\
\text { і поваги }\end{array}$ \\
\hline Професійна компетентність & $0,681 * *$ & $0,542 *$ & $0,497 *$ \\
\hline Менеджмент & $0,456^{*}$ & $0,668^{* *}$ & $0,642 * *$ \\
\hline Автономія (незалежність) & $0,281 *$ & $0,261 *$ & $0,994 * *$ \\
\hline Стабільність & $0,629 * *$ & $0,278^{*}$ & $-0,342 *$ \\
\hline Слугування добру & $0,404 *$ & & $-0,738^{* *}$ \\
\hline Конкуренція & $0,168^{*}$ & $0,587^{* *}$ & $-0,798 * *$ \\
\hline Інтеграція стилів життя & & $0,241 *$ & $0,913^{* *}$ \\
\hline Підприємництво & & $0,674 * *$ & $0,391 *$ \\
\hline
\end{tabular}

мією (Ав), стабільністю (Ст), допомогою людям (Сд) та на 5\% із показником «конкуренція» (Ко). Установлено додатні кореляційні зв'язки $(\rho \leq 0,01)$ між прагненням до влади (Пв) та професійною компетентністю (Пк), менеджментом (Ме), автономією (Ав), стабільністю (Ст), конкуренцією (Ко), інтеграцією стилів життя (Ісж), підприємництвом (Пі). Установлено наявність додатних кореляційних зв'язків між тенденцією до групового визнання і поваги (Тп) та професійною компетентністю (Пк), менеджментом (Ме), автономією (Ав), інтеграцією стилів життя (Ісж), інтеграцією стилів життя (Ісж), підприємництвом (Пі); також виявлено від'ємний кореляційний зв'язок (p<0,01) із показниками «стабільність» (Ст), «допомога людям» (Сд), «конкуренція» (Ко).

Таким чином, результати емпіричного дослідження дали змогу виявити значущі додатні та від'ємні кореляційні зв'язки на рівні $\mathrm{p}<0,01$ та $\mathrm{p}<0,05$ між показниками ціннісних орієнтацій та показниками мотиваторів соціально-психологічної активності менеджерів із різним рівнем успішності діяльності.

Аналіз профілів ціннісних орієнтацій дав змогу описати специфіку їх прояву у менеджерів різного рівня успішності діяльності, що зображені на рис. 1. Значення кожної позначки на графіку являє собою середню арифметичну показників,

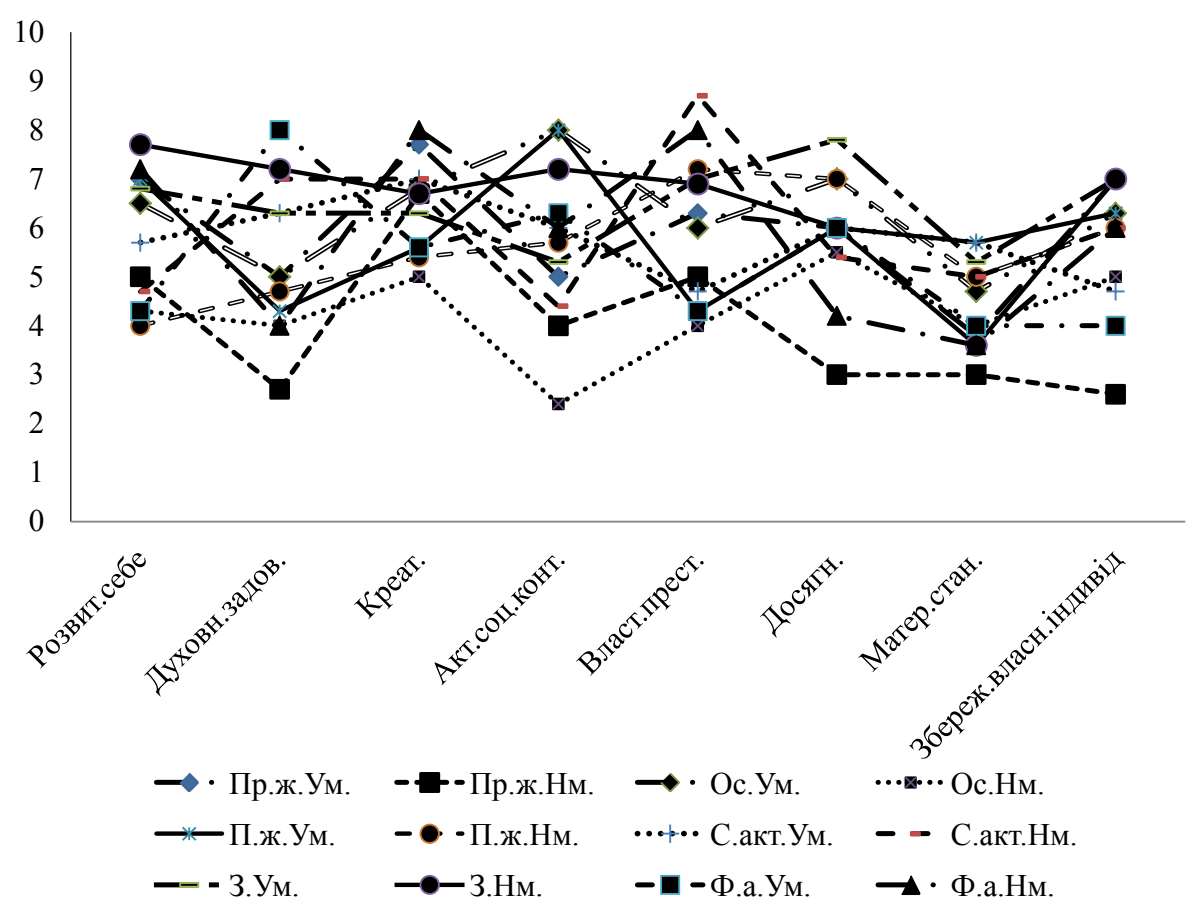

Рис. 1. Профілі показників ціннісних оріснтацій особистості успішних і не успішних менеджерів 
що вивчаються. На осі ОХ відкладено показники що вивчаються, на осі ОУ-значення показників.

Менеджери з низьким рівнем успішності мають бажання вносити у сферу своєї професійної діяльності елементи творчості, але швидко втомлюються через нові методи в організації діяльності. Вони не піклуються про власні досягнення, прагнуть до обмеження своєї активності. За досягнення яких-небудь значущих результатів відразу заспокоюються, часто образливі у разі негативної оцінки їхніх професійних здібностей, прагнуть до прагматичності, пошуку конкретної вигоди від професійної діяльності. Іноді такі люди бувають неприховано цинічні, відкрито говорять про свої меркантильні інтереси у ситуації виконання будьяких операцій у своїй діяльності.

Так, установлено, що менеджери з високим рівнем успішності прагнуть до колегіальності в роботі, встановлення сприятливих взаємовідносин із колегами, домагаються визнання в суспільстві шляхом вибору найбільш соціально схвалюваної роботи, яка могла б підкреслити їх індивідуальну своєрідність і неповторність.

Висновки. Сучасне суспільство вже протягом декількох років переживає період зміни ціннісних засад усіх сфер життя людини, у тому числі іiї професійної діяльності. На підставі особистих цінностей людини формується певний комплекс ціннісних орієнтацій, соціальних установок, що мають для суб'єкта стійкий життєвий сенс, на підставі яких здійснюється вибір пріоритетного напряму професійної діяльності, і більшість менеджерів намагається зробити на цьому ефективну кар'єру.

Відповідно до мети цієї роботи, на основі результатів психодіагностичних досліджень проаналізовано структуру, рівні вираженості і внесок професійних мотивів у професіоналізм діяльності менеджерів, що зумовлюють успішність їхньої професійної діяльності. На першому етапі емпіричного дослідження за допомогою методу кореляційного аналізу досліджено статистично значущі взаємозв'язки між показниками мотиваційно-ціннісної структури особистості та соціально-психологічною активністю менеджерів із різним рівнем успішності.

Доведено існування від'ємних кореляційних зв'язків $(\rho \leq 0,01)$ між досягненням успіху та професійною компетентністю, менеджментом, автономією, стабільністю, допомогою людям, конкуренцією, інтеграцією стилів життя і додатний кореляційний зв'язок із підприємництвом.

Установлено наявність додатних кореляційних зв'язків між тенденцією до групового визнання і поваги та професійною компетентністю, менеджментом, автономією, інтеграцією стилів життя, підприємництвом, також виявлено від'ємний кореляційний зв' язок $(\mathrm{p}<0,01)$ з показниками «стабільність», «допомога людям», «конкуренція». Таким чином, результати емпіричного дослідження дали змогу виявити значущі додатні та від'ємні кореляційні зв'язки на рівні $\mathrm{p}<0,01$ та $\mathrm{p}<0,05$ між показниками ціннісних орієнтацій та показниками мотиваторів соціально-психологічної активності менеджерів із різним рівнем успішності.

Використання якісного аналізу даних (метод «асів» та «профілів») дав змогу згрупувати осіб, які відрізняються рівнім успішності в діяльності менеджера. Аналіз профілів ціннісних орієнтацій дав змогу описати специфіку їх прояву у менеджерів різного рівня успішності у діяльності.

Аналіз профілів мотиваційно-ціннісної структури особистості не успішних менеджерів демонструє наявність у діяльності домінування креативності над іншими життєвими цінностями, профіль цього типу відрізняється дуже низьким значенням досягнення та активних соціальних контактів; у сфері освіти характерно збереження власної індивідуальності, але низькі показники активних соціальних контактів та власного престижу.

Виявлено, що менеджери з низьким рівнем успішності мають бажання вносити у сферу своєї професійної діяльності елементи творчості, але швидко втомлюються через нові методи в організації діяльності. Вони не піклуються про власні досягнення, прагнуть до обмеження своєї активності. За досягнення яких-небудь значущих результатів відразу заспокоюються, часто образливі у разі негативної оцінки їхніх професійних здібностей, прагнуть до прагматичності, пошуку конкретної вигоди від професійної діяльності. Іноді бувають неприховано цинічні, відкрито говорять про свої меркантильні інтереси у ситуації виконання будь-яких операцій у своїй діяльності.

Установлено, що менеджери з високим рівнем успішності в діяльності прагнуть до найбільш повної реалізації своїх здібностей і до підвищення своєї кваліфікації, демонструють інтерес та творчій підхід у сфері діяльності, вимогливі до себе і своїх обов'язків, креативно підходять до організації та методів роботи, постійно бажають вносити в роботу різні зміни й удосконалення. Проявляють захопленість і винахідливість у реалізації професійних завдань для досягнення конкретних і відчутних результатів. Ретельно планують увесь процес діяльності для отримання задоволення від кінцевого результату. 
Дослідження особливостей мотиваційно-ціннісної структури особистості успішних менеджерів показало, що у сфері професійного життя переважає високий рівень даних за такими шка- лами: розвиток себе, креативність, досягнення, збереження власної індивідуальності, сфера освіти характеризується високими активними соціальними контактами, особистим авторитетом.

\section{Список літератури:}

1. Водопьянова Н.Е., Старченкова Е.С. Стратегии и модели преодолевающего поведения Практикум по психологии менеджмента и профессиональной деятельности / под ред. Г.С. Никифорова, М.А. Дмитриевой, В.М. Снеткова. Санкт-Петербург : Речь, 2001. С. 311-322.

2. Глушко А.Н. Основные этапы подбора и адаптации психологических методик в целях профессионального психологического отбора. Москва : ЦВМУ, 1991. 119 с.

3. История менеджмента : учебное пособие / под ред. Д.В. Валового. Москва, 1997.

4. Лебедев О.Т., Каньковская А.Р. Основы менеджмента : учебное пособие. Санкт-Петербург : МиМ, 1997.

5. Липницкий А.В. Менеджмент и конфликты. Психология менеджмента. Санкт-Петербург, 1997.

6. Никифоров Г.С. Психология менеджмента ; 2-е изд. Харьков : Гуманитарный центр, 2002. 556 с.

7. Практикум по психологии менеджмента и профессиональной деятельности / под ред. Г.С. Никифорова, М.А. Дмитриевой, В.М. Снеткова. Санкт-Петербург : Речь, 2001. 448 с.

\section{Vasylenko I.A. FEATURES OF VALUE ORIENTATIONS OF MANAGERS OF DIFFERENT LEVELS OF SUCCESS IN BUSINESS}

Today it is becoming increasingly clear that there is a need for new managers capable of constructive and effective activities in market conditions, creative activity, able to find competent solutions in a situation of uncertainty, increased risk, limited time and ready to bear responsibility. This is the msin theoretical and practical importance of solving the problem of studying the success of managers. Psychological features of the manager's activity are represented by a significant number of both foreign (R. Blake, M. Woodcock, D. Francis, J. Grayson, K. Killen, S. Kovalevsky) and domestic scientists (V. Zhigalov, J. Zavadsky, V. Lozytsia, M. Martynenko, G. Shchokin).

The purpose of the study: theoretical justification and empirical study of value orientations of managers of different levels of professional success.

The study provides a theoretical and methodological analysis of the problem of self-esteem and types of parental attitudes towards children of primary school age; the interrelations between indicators of self-estimation of children of primary school and type of parental attitude are analyzed, the correlation between the studied indicators is established. To solve these theoretical and empirical problems in the study both theoretical and diagnostic (psychometrically sound and reliable) methods and techniques were used.

In accordance with the purpose of the work, the structure, levels of expression and contribution of professional values of managers that determine the success of their professional activities are analyzed on the basis of the results of psychodiagnostic research. At the first stage of empirical research using the method of correlation analysis (according to K. Pearson), significant relationships between indicators of motivational and value structure of personality and socio-psychological activity of managers are analyzed, statistically significant at $1 \%$ and $5 \%$ levels positive and negative correlations between indicators of value orientations and indicators of motivators of social and psychological activity of managers with low and high levels of success. According to the results of qualitative analysis, the specifics of value orientations in managers of different levels of success in activities are established.

Key words: value orientations, indicators of value orientations, motivators of social and psychological activity of managers, low and high level of success of managers'activity. 